\title{
Simultaneous HONO measurements in and above a forest canopy: influence of turbulent exchange on mixing ratio differences
}

\author{
M. Sörgel ${ }^{1}$, I. Trebs ${ }^{2}$, A. Serafimovich ${ }^{3}$, A. Moravek $^{2}$, A. Held ${ }^{1}$, and C. Zetzsch ${ }^{1,4}$ \\ ${ }^{1}$ University of Bayreuth, Atmospheric Chemistry Research Laboratory, 95440 Bayreuth, Germany \\ ${ }^{2}$ Max Planck Institute for Chemistry, Biogeochemistry Department, P.O. Box 3060, 55020 Mainz, Germany \\ ${ }^{3}$ University of Bayreuth, Department of Micrometeorology, 95440 Bayreuth, Germany \\ ${ }^{4}$ Fraunhofer Institute for Toxicology and Experimental Medicine, 30625 Hannover, Germany
}

Received: 13 August 2010 - Published in Atmos. Chem. Phys. Discuss.: 3 September 2010

Revised: 10 January 2011 - Accepted: 17 January 2011 - Published: 31 January 2011

\begin{abstract}
We have combined chemical and micrometeorological measurements to investigate the formation and distribution of HONO throughout a forest canopy. HONO was measured simultaneously at two heights, close to the forest floor and just above canopy. The turbulent exchange between the forest and the atmosphere above was studied using vertical profiles of eddy covariance measurements of wind velocity, sonic temperature, water vapour and $\mathrm{CO}_{2}$. $\mathrm{HONO}$ mixing ratios at both heights showed typical diel cycles with low daytime values ( $\sim 80 \mathrm{ppt})$ and high nighttime values (up to $500 \mathrm{ppt}$ ), but were influenced by various sources and sinks leading to mixing ratio differences (above canopy minus below) of up to $+240 \mathrm{ppt}$ at nighttime. In the late afternoon and early night mixing ratios increased at higher rates near the forest floor, indicating a possible ground source. Due to the simultaneous decoupling of the forest from the air layer above the canopy, mixing ratio differences reached about -170 ppt. From the late night until the early morning mixing ratios above the forest were typically higher than close to the forest floor. For some cases, this could be attributed to advection above the forest, which only partly penetrated the canopy. Measured photolysis frequencies above and below the forest canopy differed by a factor of 10-25 resulting in HONO lifetimes of about $10 \mathrm{~min}$ above and 100-250 min below the canopy at noontime. However, these differences of the main daytime HONO sink were not evident in the mixing ratio differences, which were close to zero during the morning hours. Effective turbulent exchange due to a complete coupling of the forest to the air layer above the canopy in
\end{abstract}

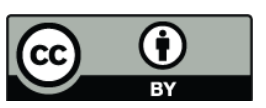

Correspondence to: M. Sörgel (matthias.soergel@uni-bayreuth.de) the morning has offset the differences caused by the daytime photolytic sink and added to the interplay between different HONO production and loss processes.

\section{Introduction}

Nitrous acid ( $\mathrm{HONO}, \mathrm{HNO}_{2}$ ) is currently gaining substantial attention due to its contribution to the tropospheric $\mathrm{OH}$ radical production, which is the "detergent" of the atmosphere. Besides its importance for the atmospheric oxidation potential, it contributes to acid and nutrient deposition to the biosphere. Moreover, growing concern exists about possible health effects due to the formation of nitrosamines (Hanst et al., 1977; Pitts et al., 1978) where HONO acts as the nitrosating agent, especially in indoor environments, e.g., so called third hand smoke after wall reactions of HONO with nicotine (Sleiman et al., 2010). Despite three decades of research since the first unequivocal detection of HONO in the atmosphere (Perner and Platt, 1979), HONO formation processes in the atmosphere are still under discussion, especially during daytime when large discrepancies were found between mixing ratios calculated from known gas-phase chemistry and measured daytime mixing ratios (Kleffmann et al., 2005). In the absence of light the most favoured formation reaction is the heterogeneous disproportionation of nitrogen dioxide $\left(\mathrm{NO}_{2}\right)$ :

$2 \mathrm{NO}_{2}+\mathrm{H}_{2} \mathrm{O} \rightarrow \mathrm{HONO}+\mathrm{HNO}_{3}$

This reaction has been extensively studied on different materials like fluorinated polymers and different types of glass as reviewed by Lammel and Cape (1996), but also on building materials like concrete (Trick, 2004). It was found to

Published by Copernicus Publications on behalf of the European Geosciences Union. 
be first order in $\mathrm{NO}_{2}$ and water vapour (Sakamaki et al., 1983; Pitts et al., 1984; Svennson et al., 1987; Jenkin et al., 1988). A mechanism involving the formation of the $\mathrm{NO}_{2}$ dimer $\left(\mathrm{N}_{2} \mathrm{O}_{4}\right)$ in the gas phase was proposed (FinlaysonPitts et al., 2003), but is not important in the real atmosphere (Kleffmann et al., 1998; Gustafsson et al., 2008). Recently, evidence for a mechanism involving reaction between adsorbed $\mathrm{NO}_{2}$ and $\mathrm{H}\left(\mathrm{NO}_{2}\right.$ (ads) $+\mathrm{H}($ ads $) \rightarrow \mathrm{HONO}$ (ads)) present on the surface following the dissociation of chemisorbed $\mathrm{H}_{2} \mathrm{O}$ was found in a study on mineral dust particles with isotopically labelled water (Gustafsson et al., 2008), but the results are probably not transferable from laboratory to field conditions (Finlayson-Pitts, 2009). In the absence of light, $\mathrm{HONO}$ formation from $\mathrm{NO}_{2}$ on soot decreases quite rapidly and thus was concluded to be less important for atmospheric HONO formation except for freshly emitted soot (Kleffmann et al., 1999; Arens et al., 2001; Aubin and Abbatt, 2007). The mechanism was summarized as the Reaction (R2) of reducing organic compounds $\{\mathrm{C}-\mathrm{H}\}_{\text {red }}$ with $\mathrm{NO}_{2}$ (Gutzwiller et al., 2002a).

$\mathrm{NO}_{2}+\{\mathrm{C}-\mathrm{H}\}_{\mathrm{red}} \rightarrow \mathrm{HONO}+\{\mathrm{C}\}_{\mathrm{ox}}$

$\mathrm{NO}+\mathrm{NO}_{2}+\mathrm{H}_{2} \mathrm{O} \rightarrow 2 \mathrm{HONO}$

$\mathrm{HNO}_{3}($ ads $)+\mathrm{NO}(g) \rightarrow \mathrm{HONO}+\mathrm{NO}_{2}$

A similar reaction like Reaction (R2) was postulated for the aqueous phase (Gutzwiller et al., 2002b; Ammann et al., 2005), but only proceeds at a relevant rate at high $\mathrm{pH}$ levels, since it is based on the well known charge transfer reaction of phenolate with $\mathrm{NO}_{2}$. The Reactions R3 (via the intermediate $\mathrm{N}_{2} \mathrm{O}_{3}$ ) and Reaction (R4), involving $\mathrm{NO}$ proposed from field measurements (Calvert et al., 1994; Andres-Hernandez et al., 1996; Saliba et al., 2001) could neither explain laboratory results under low $\mathrm{NO}_{\mathrm{x}}$ conditions (Svennson et al., 1987; Jenkin et al., 1988; Kleffmann et al., 1998; Kleffmann et al., 2004;) nor field experiments with low NO mixing ratios (Harrison and Kitto, 1994).

The daytime HONO formation recently discussed in an overview paper by Kleffmann (2007) was found to be about 60 times faster (Kleffmann et al., 2005) than the heterogeneous nighttime formation, and is even more controversial. There are a variety of proposed sources dealing with photoenhanced $\mathrm{NO}_{2}$ reduction including $\mathrm{NO}_{2}$ reduction on irradiated mineral surfaces like $\mathrm{TiO}_{2}$ (Gustafsson et al., 2006; Ndour et al., 2008). Many studies focussed on the reduction of $\mathrm{NO}_{2}$ involving organic photosensitizers (George et al., 2005) like hydrocarbons on soot (Monge et al., 2010) or humic acids (Stemmler et al., 2006; Stemmler et al., 2007). As already proposed from smog chamber experiments (Killus and Whitten, 1990), photolysis of deposited $\mathrm{HNO}_{3} /$ nitrate on surfaces was suggested as a daytime HONO source for rural environments by Zhou et al. (2002a, b, 2003) from field studies at low $\mathrm{NO}_{\mathrm{x}}$ conditions. The mechanism is still not convincing since the photolysis of $\mathrm{HNO}_{3}$ was not found to be a photolytic source of HONO in chamber experiments (Rohrer et al., 2005). Quantum yields for $\mathrm{HNO}_{3} /$ nitrate photolysis are too low in the gas phase and in solution (Zhou et al., 2003; Kleffmann, 2007), but this process can be enhanced at surfaces (Finlayson-Pitts, 2009) or via organic photosensitizers as speculated by Kleffmann (2007). An additional source may be the photolysis of o-nitrophenols (Bejan et al., 2006) depending on pollution levels that govern the formation of nitrophenols.

A problem that arises when comparing kinetics derived from laboratory experiments with those calculated from field data is that the heterogeneous production may be decoupled from the release to the atmosphere (Finlayson-Pitts, 2009). Desorption processes of HONO formed at the surface or deposited to the surface might be governed by co-adsorption of water molecules as, e.g., formulated in a model developed for chamber measurements (Trick, 2004). Furthermore, the condensation of water vapour might block surface active sites (Lammel and Cape, 1996). This was found to inhibit photoenhanced reactions (Gustafsson et al., 2006; Stemmler et al., 2007). The relative humidity ( $\mathrm{RH})$ dependence of HONO mixing ratios was investigated in several field (Stutz et al., 2004; Su et al., 2008; Qin et al., 2009; Yu et al., 2009) and laboratory studies (Ammann et al., 1998; Wainmann et al., 2001; Arens et al., 2002; Trick, 2004) as well as its relation to nitrite in dew (Rubio et al., 2002, 2008; He et al., 2006). The findings of all studies do not allow a simple interpretation of the relationship between $\mathrm{RH}$ and HONO mixing ratios as already stated by Lammel and Cape (1996), but should be taken into account for modelling activities (Stutz et al., 2004). For the heterogeneous formation not only the chemistry at the surface and adsorption/desorption of reactants and products are important, but also the available surface area per volume air $(\mathrm{S} / \mathrm{V})$ and the dispersion or accumulation of formed HONO depending on turbulent transport and, hence, on atmospheric stability. Correlations of HONO mixing ratios or $\mathrm{HONO} / \mathrm{NO}_{\mathrm{x}}$ ratios, which should be less sensitive to boundary layer processes, with the aerosol surface concentration $\left(\mathrm{S} / \mathrm{V}_{\text {aerosol }}\right)$ were often found (Lammel and Perner, 1988; Notholt et al., 1992; Andres-Hernandez et al., 1996), but a complete separation from boundary layer processes was not possible (Andres-Hernandez et al., 1996; Reisinger, 2000). Recent studies (Qin et al., 2009; Yu et al., 2009) found a good correlation with PM10 (S/ $\left.\mathrm{V}_{\text {aerosol }}\right)$, but concluded that the aerosol surface is of minor importance compared to the ground surface. Thus, the relative importance of aerosol surface versus ground surface (vegetation, buildings) depends on the respective surface areas available, on the nature of these surfaces and on the turbulent mixing and the meteorological conditions at a specific site. There is ample evidence from other ground-based field measurements (Stutz et al., 2002; Veitel, 2002; Kleffmann et al., 2003; Zhang et al., 2009), aircraft profiles (Zhang et al., 2009) and modeling studies (Vogel et al., 2003) that the ground surface is a major source of HONO. Hence, turbulent exchange has a 
significant impact on near surface HONO mixing ratios as already proposed by Febo et al. (1996). These authors found a good correlation of HONO with radon, which is exclusively emitted from the ground. Furthermore, profiles from recent aircraft measurements were closely related to atmospheric stability (Zhang et al., 2009).

The efficiency of the physicochemical and/or surface HONO production and of the uptake by forest vegetation and soils is determined by the interaction of turbulent transport and chemical reactions in and above the forest canopy. In this paper, we have investigated HONO mixing ratio differences between above and below a forest canopy using the coupling processes by coherent exchange (Thomas and Foken, 2007) between different canopy layers and the air above the canopy. The definition of so-called coupling regimes is based on the detection of coherent structures, which are organized structures in the turbulent (stochastic) flow. For the first time, we demonstrate how measurements of HONO can be combined with a micrometeorological approach in tall vegetation, providing an appropriate tool to investigate processes affecting HONO mixing ratios measured within and above the canopy.

\section{Experimental}

During the Intensive Observation Periods (IOPs) of the EGER project (Exchan $G E$ processes in a mountainous Region) simultaneous measurements of micrometeorological and chemical parameters were made in order to investigate the exchange of energy and matter between a forest ecosystem and the atmosphere. The "Waldstein-Weidenbrunnen" research site is located in the Fichtelgebirge mountains in northeast Bavaria $\left(50^{\circ} 09^{\prime} \mathrm{N}, 11^{\circ} 52^{\prime} \mathrm{E}, 775 \mathrm{~m}\right.$ above sea level), Germany, in a rural forested region. There are no larger towns to the east within $70 \mathrm{~km}$. The motorway (A9) is about $9 \mathrm{~km}$ to the west, running form north to south. The cities of Kulmbach ( 30000 inhabitants) and Bayreuth (73000 inhabitants) are situated $30 \mathrm{~km}$ west and south-west, respectively. This site has been extensively studied by the University of Bayreuth (Matzner, 2004, Gerstberger et al. 2004) and is a part of the FLUXNET (Baldocchi et al., 2001). The site is covered by a Norway spruce (Picea abies (L.) Karst.) forest with a canopy height of 23-25 m (Staudt and Foken, 2007). An extensive description of the experiment and the meteorological conditions can be found in the experiment documentation by Serafimovich et al. (2008). Furthermore, an extensive overview with a detailed description of the aims of the EGER project and the instrumental setup during the IOPs is given in Foken et al. (2011). The measurements discussed in this paper were made at three different sites in the forest stand. A thin $36 \mathrm{~m}$ high tower ("turbulence tower") located about $60 \mathrm{~m}$ southeast of the main tower ( $31 \mathrm{~m}$ walk-up tower) was used for (undisturbed) turbulence measurements. The forest floor exchange site was located about $30 \mathrm{~m}$ northwest of the main tower.
Simultaneous measurements of HONO were conducted at a height of $24.5 \mathrm{~m}$ (just above canopy) on the main tower and close to the forest floor in $0.5 \mathrm{~m}$ at the forest floor exchange site from 13 to 25 September 2007. HONO was measured by two LOPAP instruments ( $L O$ ng Path Absorption Photometer, QUMA Elektronik \& Analytik, Wuppertal, Germany). The LOPAP is based on a wet chemical technique, with fast sampling of HONO as nitrite in a stripping coil and subsequent detection as an azo dye using long path absorption in $2.4 \mathrm{~m}$ long Teflon AF tubing. A detailed description of the instrument has been given by Heland et al. (2001) and Kleffmann et al. (2002). The instruments were placed outside in the forest or directly on the tower in ventilated aluminum boxes without temperature control. The temperature of the stripping coils was kept constant at $20^{\circ} \mathrm{C}$ by thermostats to assure constant sampling conditions.

From 27 September to 3 October both LOPAPs were compared side-by-side near the forest floor at a height of $1 \mathrm{~m}$. The sampling inlets had a distance of about $50 \mathrm{~cm}$ and were directed northwards to sample perpendicularly to the westerly flow. No T-piece was used as inlet to avoid artificial HONO formation or adsorption on the inner walls of the tubing. Both instruments were supplied with the same reagents via T-pieces.

Temperature and humidity profiles were measured at the main tower using Frankenberger-type psychrometers (Frankenberger, 1951). The relative humidity (RH) was calculated from the dry and wet bulb temperature of the psychrometers using the Magnus formula after Sonntag (1990) for the saturation vapour pressure and the Sprung formula for the actual vapour pressure (Foken, 2008). Psychrometers were mounted on the main tower at $0,2,5,12,21$ and $32 \mathrm{~m}$. Additionally, visibility was measured with a PWD11 (Vaisala,Vantaa, Finland) present weather detector mounted on the main tower.

Aerosol number size distributions were measured on the main tower at $28 \mathrm{~m}$ height using a Scanning Mobility Particle Sizer (SMPS, Grimm, Ainring, Germany). Boundary layer heights were derived from SODAR (SOund Detection And Ranging, Metek Meteorologische Messtechnik, Elmshorn, Germany) measurements at a nearby clearing.

Vertical profiles of nitrogen oxides $\left(\mathrm{NO}\right.$ and $\left.\mathrm{NO}_{2}\right)$ were measured on the main tower and on the forest floor exchange site by red-filtered detection of the chemiluminescence produced by the reaction of $\mathrm{NO}$ with $\mathrm{O}_{3}$ (CLD 780 TR, ECO Physics, Duernten, Switzerland). $\mathrm{NO}_{2}$ was photolytically converted to NO by exposure of the sample air to a solidstate blue-light converter (Meteorologie Consult, Königstein, Germany) and subsequently detected by the chemiluminescence analyzer. Sample air was drawn through $55 \mathrm{~m}$ of nontransparent and heated PFA tubing from each inlet height. Inlet heights of the system were located at $0.05,0.3,1,2,5$, 10,16 , and $24 \mathrm{~m}$. The lower heights of up to $2 \mathrm{~m}$ were located at the forest floor exchange site, while the upper heights were mounted at the main tower, for details see Moravek (2008). 


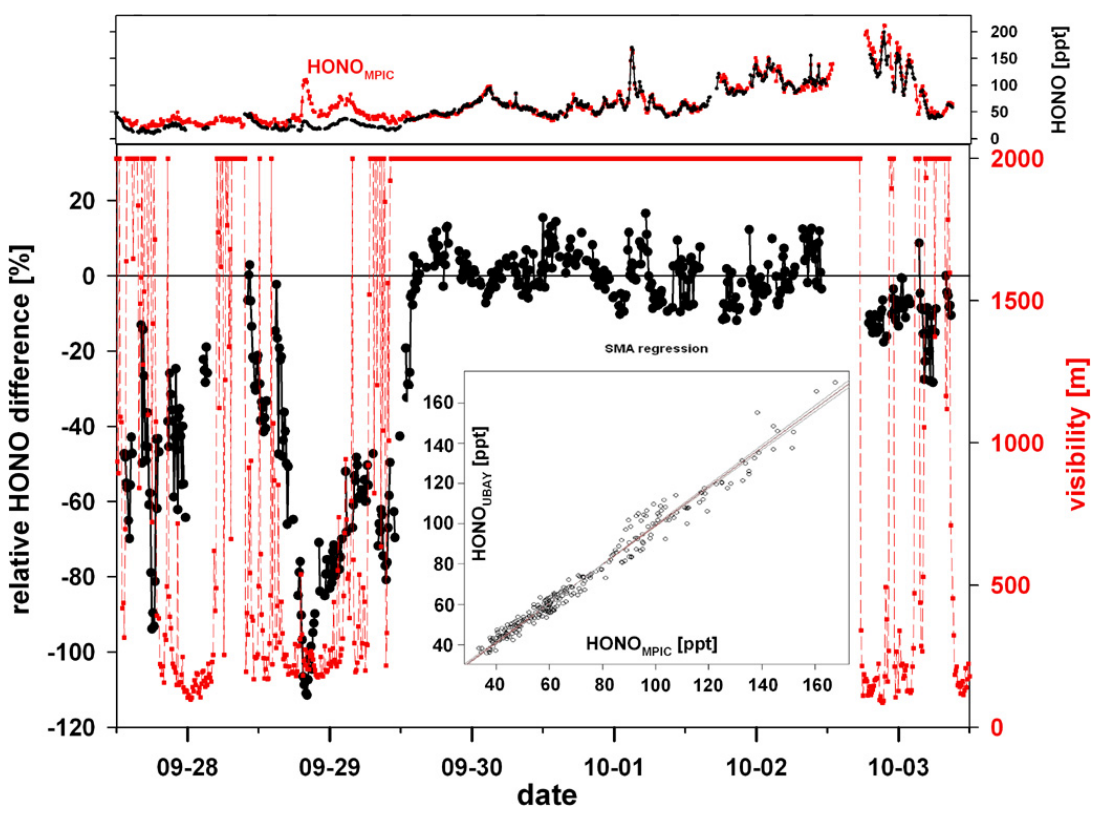

Fig. 1. Side-by-side measurements of the two LOPAP instruments from 27 September (noon) to 3 October 2007 (noon) at the "WaldsteinWeidenbrunnen" research site. Relative differences of the HONO signals (black dots) and visibility range (red squares, dashed lines, maximum range $2000 \mathrm{~m}$ ). The insert shows the regression obtained during dry conditions $(N=247)$ from 29 September (14:00 CET) to 2 October (10:00 CET) using standard major axis (SMA) regression. The upper panel shows the mixing ratios measured by the two LOPAP instruments. Missing values are due to zero air measurements and calibration of the LOPAP instruments.

To detect the coupling regimes between the subcanopy, canopy and layer above the canopy the eddy-covariance measurements were used. Six eddy-covariance systems consisting of sonic anemometers and fast response $\mathrm{CO}_{2}$ and $\mathrm{H}_{2} \mathrm{O}$ gas analyzers were installed at the turbulence tower in 2.25 , 5.5, 13, 18, 23 and $36 \mathrm{~m}$. The wavelet transform was used to detect and extract ramp-like structures (coherent structures) from high frequency measurements of wind, sound temperature, $\mathrm{CO}_{2}$ and $\mathrm{H}_{2} \mathrm{O}$ concentrations (Thomas and Foken, 2005). These structures are responsible for the turbulent coherent transport of the momentum and matter in forested ecosystems. Analysis of a sensible heat transport by coherent structures reveals the portions of the forest canopy coupled by coherent exchange with the air above the canopy (Thomas and Foken, 2007). The experimental setup and the analysis of the coupling regimes during the EGER intensive observation periods are described in more detail by Serafimovich et al. (2010).

The HONO photolysis frequency $(j(\mathrm{HONO}))$ was calculated from the $\mathrm{NO}_{2}$ photolysis frequency measured by filter radiometers (Meteorologie Consult, Königstein, Germany) according to Kraus and Hofzumahaus (1998) and Trebs et al. (2009). The radiometers were mounted on top of the main tower at a height of $28 \mathrm{~m}$, and at $2 \mathrm{~m}$ above the forest floor at the forest floor exchange site.

For statistical computing the free statistics software "R" was used (http://www.R-project.org).

\section{Results and discussion}

\subsection{Comparison of the two LOPAP instruments}

The LOPAP instruments from the University of Bayreuth (UBAY) and the Max-Planck-Institute for Chemistry (MPIC) were compared side-by-side at $1 \mathrm{~m}$ above the forest floor between 27 September and 3 October to evaluate the precision of the instruments. For this purpose the relative differences of the measured HONO mixing ratios were calculated by normalizing the difference of [HONO] UBAY minus $[\mathrm{HONO}]_{\text {MPIC }}$ by the arithmetic mean of these mixing ratios. The temporal evolution of these relative mixing ratio differences is shown in Fig. 1 together with the visibility as an indicator of foggy events. During rainy and foggy weather conditions indicated by the reduced visibility, we observed systematic deviations between the two LOPAP instruments. Large relative differences of the HONO signals during periods with low visibilities are related to fog events. Bröske et al. (2003) reported no measurable particle losses in the sampling glass coil for SOA (secondary organic aerosol) particles with diameters from 50-800 nm but Kleffmann et al. (2006) argued that large particles like fog droplets might be sampled by the coil. Thus, the sampling of fog droplets containing nitrite is a plausible explanation for deviations under wet conditions. However, this should affect both instruments by introducing more scatter and cannot explain the systematic deviation. Another potential reason could be that the surfaces 
of the inlets (first centimetre of the coils before contact with the sampling reagent) exhibited different wettabilites during these periods. During the dry conditions (visibilities of more than $2000 \mathrm{~m}$, which is the maximum detectable by the instrument) between 29 September (14:00 CET) and 2 October (10:00 CET) HONO levels ranged from $35 \mathrm{ppt}$ to $170 \mathrm{ppt}$ and the instruments agreed within $12 \%(2 \sigma)$, which is within the range of the estimated instrumental error under the given conditions (e.g., detection unit not air conditioned). Omitting the wet conditions before and after the dry period the relative errors correspond to a Gaussian distribution centred at zero. Thus, no systematic deviation of the instruments was found during dry conditions. The insert on Fig. 1 shows the correlation between the two instruments. Applying standard major axis regression analysis (Sokal and Rohlf, 1995; Legendre and Legendre, 1998), which is suitable for two random variables (e.g., Ayers, 2001) by reducing deviations perpendicularly to the regression line, yields an intercept of $2.3 \mathrm{ppt}$, which is close to the detection limit of the instruments $(3 \sigma-$ definition). The slope is 0.97 and the coefficient of determination $r^{2}=0.98$ for the dry weather period. Kleffmann (2006) used a T-piece and PFA tubing in front of the sampling units to compare two LOPAP instruments in order to avoid any influence from inhomogeneities in the sampled air. The linear correlation of these two LOPAPs was very good over a large mixing ratio range from about $200 \mathrm{ppt}$ to $1.6 \mathrm{ppb}$, with a slope of 0.993 and an intercept of $1.4 \mathrm{ppt}$. However, since it is well known that any tubing in front of the sampling unit may cause artefacts due to wall reactions of $\mathrm{NO}_{2}$ we avoided this approach. Furthermore, there was no dependency of the relative error on the friction velocity $\left(u^{*}\right)$ or the horizontal wind speed, indicating no significant influence from inhomogeneities in the sampled air. This is expected because the sampling units were only about $50 \mathrm{~cm}$ apart. At wind speeds as low as $0.5 \mathrm{~m} \mathrm{~s}^{-1}$ it took only $1 \mathrm{~s}$ to pass both sampling units, whereas the response time of both instruments is about $7 \mathrm{~min}$. Thus, small scale inhomogeneities should contribute equally to both signals.

We conclude that the LOPAP instruments can be used to reliably measure vertical HONO mixing ratio differences under dry conditions.

\subsection{Factors controlling HONO mixing ratio levels}

\subsubsection{General observations in the time series}

HONO is effectively scavenged by precipitation due to its good water solubility with a Henry's law constant of about $50 \mathrm{~mol} \mathrm{~L}^{-1} \mathrm{~atm}^{-1}$ (Sander, 1999). Precipitation was found to structure the time series ranging from 13 of September to 3 October on a time scale of about a week due to synoptic weather conditions (low and high pressure systems). Although not precisely measurable (see Sect. 3.1) due to large relative errors of both instruments during foggy conditions, HONO values were clearly lower at both heights during these wet periods. $\mathrm{HONO} / \mathrm{NO}_{\mathrm{x}}$ ratios were below $2 \%$ at both heights because (due to lower Henry's law constants of NO (about $2 \times 10^{-3} \mathrm{~mol} \mathrm{~L}^{-1} \mathrm{~atm}^{-1}$ ) and $\mathrm{NO}_{2}$ (1$4 \times 10^{-2} \mathrm{~mol} \mathrm{~L}^{-1} \mathrm{~atm}^{-1}$ ) (Sander, 1999)) $\mathrm{NO}_{\mathrm{x}}$ is not significantly influenced by precipitation scavenging or enhanced deposition on wet surfaces. During the entire IOP, three dry periods occurred between rain events. Dry periods were characterized by steadily increasing nighttime HONO mixing ratios up to $500 \mathrm{ppt}$, while $\mathrm{HONO}$ mixing ratios dropped during rain events to about $20 \mathrm{ppt}$. One of these dry periods (20-25 September) is shown in Figs. 2 and 3. Below canopy measurements of $\mathrm{HONO}, \mathrm{NO}_{\mathrm{x}}$ and $\mathrm{HONO} / \mathrm{NO}_{\mathrm{x}}$ are presented together with rain fall measurements in Fig. 2. An overview graph for above canopy meteorological (wind direction, friction velocity, temperature, relative humidity and $j(\mathrm{HONO})$ ) and chemical (NO, $\mathrm{NO}_{2}, \mathrm{HONO}$ and ozone) measurements is given in Fig. 3. During the dry period winds from south-west and south-east were dominating. Temperatures were increasing and daytime $\mathrm{RH}$ values were decreasing. The friction velocity $\left(u^{*}\right)$, which is a measure for the wind shear and thus wind generated turbulence, was calculated from eddy covariance measurements of horizontal and vertical wind speed. During the dry period $u^{*}$ is lower (especially at night) than before and afterwards. Significant NO values (at the above canopy level) were only measured during day. At the beginning of the dry period, HONO increased continuously with a rate of about $2 \mathrm{ppt} \mathrm{h}^{-1}$ without a pronounced diel cycle, although the 20 September was a clearsky day with $j$ (HONO) values of about $0.002 \mathrm{~s}^{-1}$ around noon (see Fig. 3).

An increasing trend in both the time series of the HONO mixing ratio and the $\mathrm{HONO} / \mathrm{NO}_{\mathrm{x}}$ ratio is evident. To our knowledge this type of accumulation behaviour was not reported so far, and it was not directly linked to an increase of the precursor $\mathrm{NO}_{2}$ (Fig. 3). Although clarifying the reason for this is far beyond our applied measurement setup, a mechanism that might explain these observations would be the accumulation of (photo-) chemically formed or deposited $\mathrm{HONO}$ at the surface and the subsequent release by increasing RH, according to a Langmuir-type surface mechanism proposed by Trick (2004) due to enhanced adsorption of water molecules and subsequent release of HONO, as RH increases in the late afternoon. Additionally, HONO formation due to photolysis of deposited $\mathrm{HNO}_{3}$ /nitrate as suggested by Zhou et al. (2002a, b, 2003) might be an explanation, since the precursor ("sticky" $\mathrm{HNO}_{3}$ ) is deposited efficiently to the canopy (Wolff et al., 2010) and accumulates at the needle surface (Zhou et al., 2002a).

\subsection{2 $\mathrm{S} / \mathrm{V}_{\text {ground }}$ versus $\mathrm{S} / \mathrm{V}_{\text {aerosol }}$}

The needle surface also constitutes the largest fraction of the total ground surface. Therefore, we estimated the ground surface from measurements of the projected plant surface neglecting stem and understory contributions. The average 


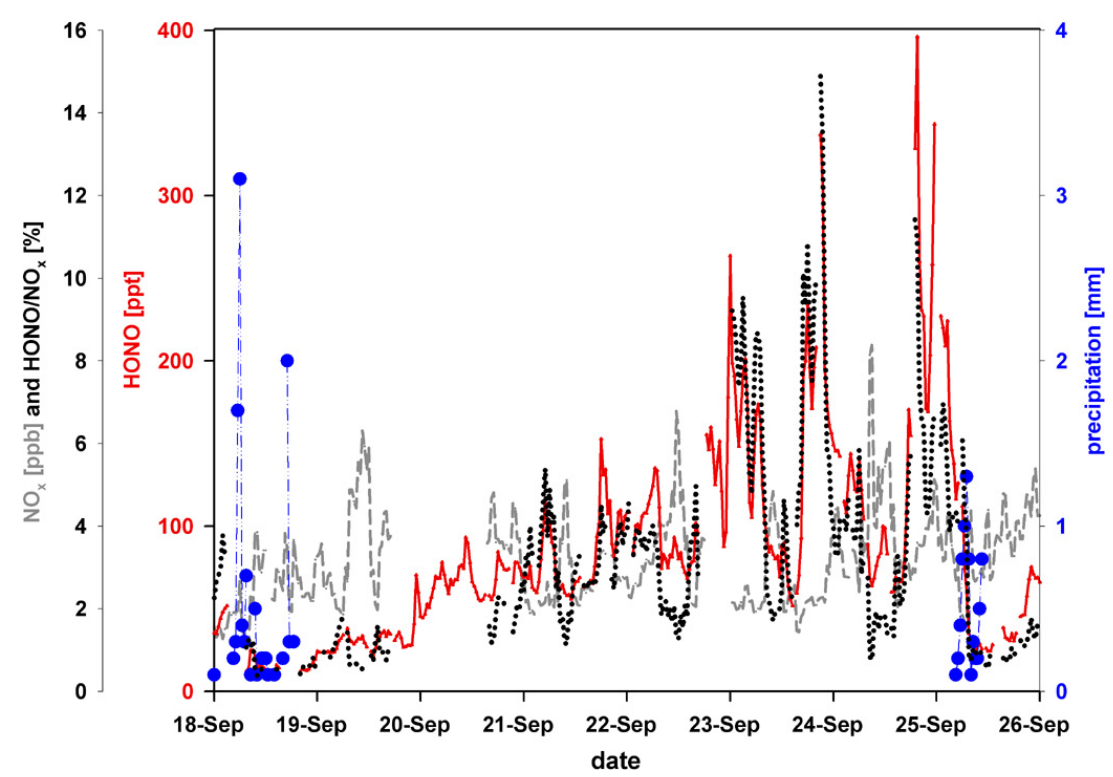

Fig. 2. Time series of $\mathrm{HONO}$ at $0.5 \mathrm{~m}$ above the forest floor (red line), $\mathrm{NO}_{\mathrm{x}}$ (grey dashed line) and $\mathrm{HONO}_{\mathrm{NO}} \mathrm{x}$ ratio (black dotted line) from 18 (00:00 CET) to 26 (00:00 CET) September 2007 at the "Waldstein-Weidenbrunnen" research site. This dry period was delimited by rain events marked with blue dots (half hourly values).

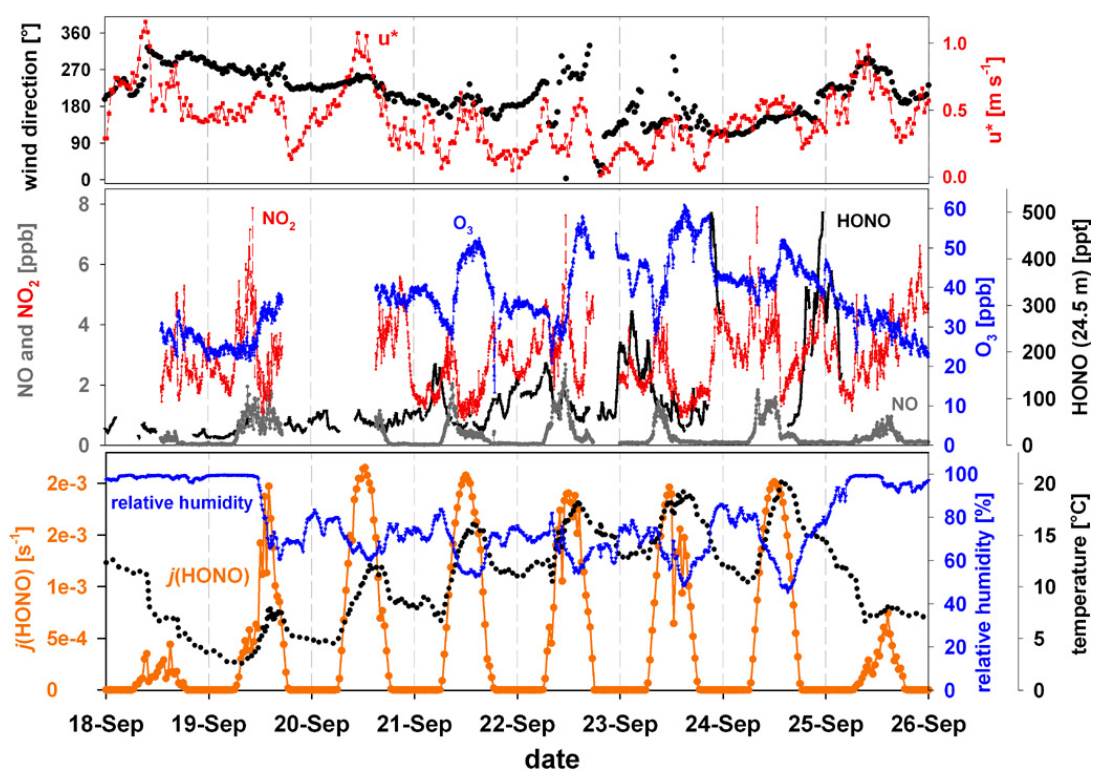

Fig. 3. The upper panel shows the wind direction above canopy $(32 \mathrm{~m})$ and the friction velocity $\left(u^{*}\right)$ at the top of the canopy $(21 \mathrm{~m})$. In the middle panel the trace gases $\left(\mathrm{NO}, \mathrm{NO}_{2}, \mathrm{O}_{3}\right.$ and $\mathrm{HONO}$ ) measured above the canopy $(24.5 \mathrm{~m})$ are presented. Time series of the $\mathrm{HONO}$ photolysis frequency $j(\mathrm{HONO})$ parameterized from the measured $\mathrm{NO}_{2}$ photolysis frequency at a height of $28 \mathrm{~m}$ (orange line and dots), relative humidity and air temperature measured at the canopy top (21 m) from 18 (00:00 CET) to 26 (00:00 CET) September 2007 at the "Waldstein-Weidenbrunnen" research site are presented in the lower panel.

PAI (Plant Area Index) of this forest stand is $5 \mathrm{~m}^{2} \mathrm{~m}^{-2}$ (Staudt et al., 2010). This projected area can be converted to a surface area by multiplying with $\pi$ for wooden parts (assuming they are round), which contribute about 20\% (5$35 \%$ (Gower et al., 1999)) to the PAI and by a factor of
2.65 derived by Oren et al. (1986) to convert the projected LAI ( $\sim 80 \%$ of PAI) to the geometric needle surface. From that simple scheme we derive a total geometric surface of the crown of $13.7 \mathrm{~m}^{2} \mathrm{~m}^{-2}\left(10.6 \mathrm{~m}^{2} \mathrm{~m}^{-2}\right.$ needle surface and $3.6 \mathrm{~m}^{2} \mathrm{~m}^{-2}$ wooden surface). From SODAR (SOund 
Detection And Ranging) measurements we inferred an average NBL (Nocturnal Boundary Layer) height of $120 \mathrm{~m}$ by a steep change in reflectivity of the sound signal. Using this value as an upper limit for the volume $\left(1 \mathrm{~m}^{2}\right.$ as base area), and for a lower limit ground surface the geometric needle surface of the canopy, we get a $S / \mathrm{V}_{\text {ground }}$ of $0.1 \mathrm{~m}^{-1}$, which is an order of magnitude higher than e.g. reported by Yu et al. (2009). However, Yu et al. (2009) took only the inverse of the mixed layer height as $\mathrm{S} / \mathrm{V}_{\text {ground }}$, not accounting for any roughness of the surface. Especially, during nighttime the boundary layer height represents an upper limit for the volume, because mixing is very limited within the stable thermally stratified NBL (Stull, 1988). Vogel et al. (2003) used a value of $0.1 \mathrm{~m}^{-1}$ to model heterogeneous HONO production in the lowest box of their model but increased S/V ground to $0.3 \mathrm{~m}^{-1}$, which matched the observations better. This is consistent with our observations that $\left(\mathrm{S} / \mathrm{V}_{\text {ground }}\right) 0.1 \mathrm{~m}^{-1}$ reflects a lower limit. In contrast, the $S / \mathrm{V}_{\text {ground }}$ values given by Lammel and Cape (1996) were an order of magnitude higher, e.g., considering vegetation surfaces with $0.6-1.4 \mathrm{~m}^{-1}$ (for a mixed layer height of $100 \mathrm{~m}$ ). Additionally, we calculated the aerosol surface from the measured aerosol number size distributions and we found that $\mathrm{S} / \mathrm{V}_{\text {aerosol }}$ was typically less than $1 \%$ of $S / \mathrm{V}_{\text {ground. }}$. Due to the different reactivity and gas diffusivity for ground and aerosol surfaces a direct comparison of $S / V_{\text {ground }}$ and $S / V_{\text {aerosol }}$ is complicated. Since we measured close to surfaces and these surface areas are about two orders of magnitude larger than the respective aerosol surface for the whole mixed layer, we expect the contribution of aerosol surfaces to HONO formation to be of minor importance in our study. This is in line with measurements from Kleffmann et al. (2003) who found that gradients of $\mathrm{HONO}$ were not related to gradients in $\mathrm{S} / \mathrm{V}_{\text {aerosol }}$.

A decrease of the boundary layer height increases $\mathrm{S} / \mathrm{V}_{\text {ground. }}$. Hence, with the same surface more HONO is concentrated in a smaller volume. However, at the same time turbulence is suppressed during these stable conditions. This reduces the exchange between the atmosphere and the surface.

\subsubsection{Nighttime HONO conversion frequencies}

HONO nighttime conversion frequencies $\mathrm{F}_{\mathrm{HONO}}$, night from the heterogeneous disproportionation of $\mathrm{NO}_{2}$ (cf. Reaction $\mathrm{R} 1+\mathrm{R} 2$ ) can be estimated for the dry periods. Su et al. (2008) discussed the problem of different scaling methods for HONO production and suggested to use a combined scaling approach of different quantities emitted close to the ground like black carbon $(\mathrm{HONO} / \mathrm{BC})$ or carbon monoxide (HONO/CO), and the "classical" $\mathrm{HONO} / \mathrm{NO}_{2}$ or $\mathrm{HONO} / \mathrm{NO}_{\mathrm{x}}$. The scaling was (originally) introduced to reduce influences from boundary layer processes such as dilution or vertical mixing. However, local sources of the scaling quantities will affect the ratio (Su et al., 2008). As discussed above, humid surfaces or precipitation will also alter the $\mathrm{HONO} / \mathrm{NO}_{\mathrm{x}}$ ratio due to different solubilities as well as the advection of $\mathrm{NO}_{\mathrm{x}}$ from road traffic during the morning hours at our site. Due to the lack of carbon monoxide (CO) and black carbon (BC) measurements we use the $\mathrm{NO}_{\mathrm{x}}$ scaling approach, which was used in many other studies (e.g. Sjödin, 1988; Alicke et al., 2002; Kleffmann et al., 2003;). The approach of Alicke et al. (2002) for inferring conversion frequencies, taking a linear increase of $\mathrm{HONO}$ during nighttime divided by the average $\mathrm{NO}_{2}$ mixing ratio in this time interval is most commonly used.

$\overline{\mathrm{F}_{\mathrm{HONO}, \text { night }}}=\frac{[\mathrm{HONO}]\left(t_{2}\right)-[\mathrm{HONO}]\left(t_{1}\right)}{\left(t_{2}-t_{1}\right)\left[\mathrm{NO}_{2}\right]_{\text {night }}}$

There is still no reliable way of inferring HONO conversion frequencies using objective criteria. Yu et al. (2009) used a fixed time interval from 18:00 local time (LT) to midnight (LT) to determine HONO conversion frequencies. This approach leads to a very large scatter in our conversion frequencies. In addition, it yields mainly negative conversion frequencies in the lower height, because HONO increases already before sunset, thus starting at higher levels, and peak mixing ratios are reached before midnight. We also tried an approach different from the "classical" one, not using the maximum HONO mixing ratio as end point but the maximum $\mathrm{HONO} / \mathrm{NO}_{\mathrm{x}}$ ratio that can be regarded as the maximum amount of $\mathrm{HONO}$ produced by $\mathrm{NO}_{\mathrm{x}}$.

1. Evaluating individual increases of HONO by the "classical" approach, excluding advection events and other disturbances: This approach could be used for evaluating data from five nights of the whole IOP (1325 September) and yielded a value of $\mathrm{F}_{\mathrm{HONO} \text {,night }} \pm$ $\sigma=(1.1 \pm 0.65) \% \mathrm{~h}^{-1}$ for the measurements above the canopy and a value of $(0.75 \pm 0.45) \% \mathrm{~h}^{-1}$ close to the ground. The lower value for the lower height may be caused by choosing the starting point after sunset, whereas the first pronounced increase in HONO mixing ratios occurs already in the hours before sunset. Thus, the starting mixing ratio level is already higher at the lower height, whereas the increase at the upper height normally occurs later and is therefore completely captured. However, the influence of photochemistry has to be excluded for a proper comparison of heterogeneous production, and therefore we cannot use the data before sunset. The values of $\mathrm{F}_{\mathrm{HONO}}$,night at both heights agree within their standard deviation (variation over five nights) and are consistent with literature values between $0.4 \% \mathrm{~h}^{-1}$ and $1.8 \% \mathrm{~h}^{-1}$ recently summarized by $\mathrm{Su}$ et al. (2008). The value for the upper height also compares quite well with a value of $1.4 \pm 0.4 \% \mathrm{~h}^{-1}$ reported by Yu et al. (2009), which was not included in the comparison by $\mathrm{Su}$ et al. (2008).

2. Evaluating the period from sunset to the maximum $\mathrm{HONO} / \mathrm{NO}_{\mathrm{x}}$ ratio: Conversion frequencies inferred by 


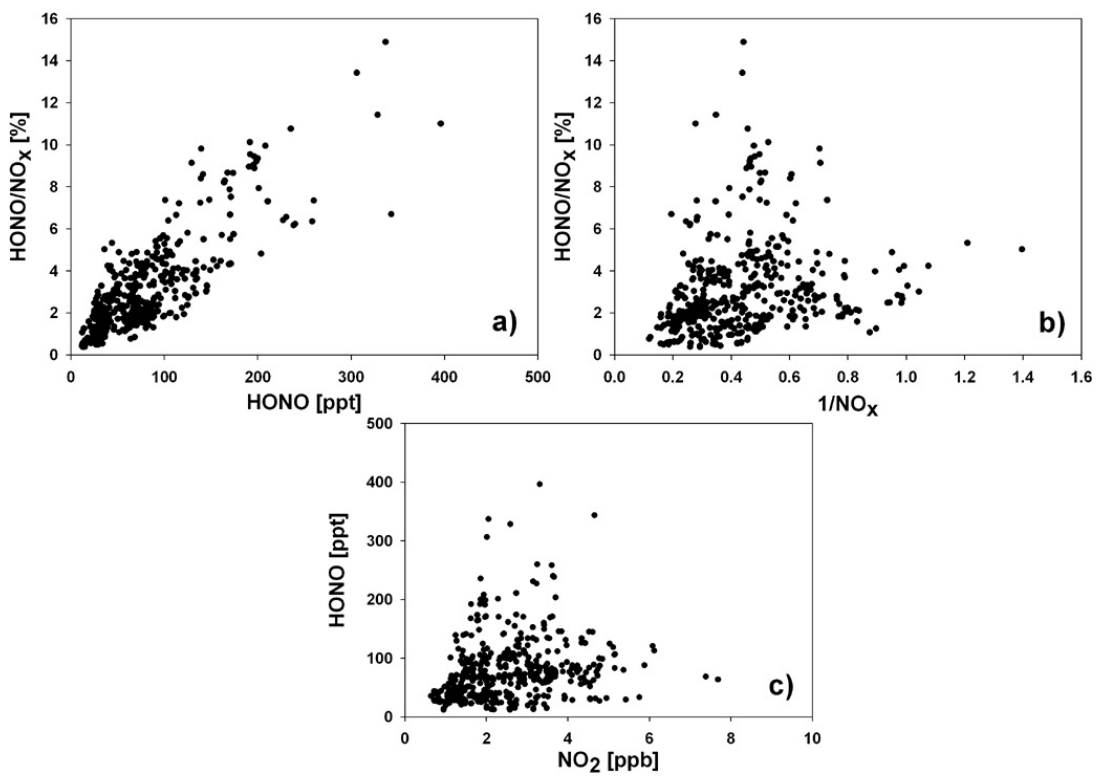

Fig. 4. Relationships of $\mathrm{HONO}$ and $\mathrm{NO}_{\mathrm{x}}$ for the measurement height close to the forest floor $(0.5 \mathrm{~m})$ for the period $13-25 \mathrm{September}$ at the "Waldstein-Weidenbrunnen" research site. The upper graphs $(\mathbf{a}, \mathbf{b})$ show a better correlation of $\mathrm{HONO} / \mathrm{NO}_{\mathrm{x}}$ to $\mathrm{HONO}$ than to $1 / \mathrm{NO}_{\mathrm{x}}$, i.e. variations in $\mathrm{HONO} / \mathrm{NO}_{\mathrm{x}}$ are more likely explained by variations in $\mathrm{HONO}$ mixing ratios than by $\mathrm{NO}_{\mathrm{x}}$ values.

this approach are identical to the "classical" ones for the conditions during our campaign. The values and the variation of $\mathrm{HONO} / \mathrm{NO}_{\mathrm{x}}$ ratios were mainly correlated to HONO mixing ratios (see Fig. 4a, b). Therefore, the $\mathrm{HONO} / \mathrm{NO}_{\mathrm{x}}$ maxima occurred simultaneously with the maximum HONO mixing ratios (Fig. 2). Additionally, $\mathrm{HONO}$ mixing ratios were nearly independent of its precursor $\mathrm{NO}_{2}$ (see Fig. 4c). A direct correlation could not be expected since the HONO formation rate $d \mathrm{HONO} / d t$ should correlate with $\mathrm{NO}_{2}$ instead of HONO mixing ratios, due to first order formation of HONO from $\mathrm{NO}_{2}$. Nevertheless, assuming similar heterogeneous conversion rates, higher $\mathrm{NO}_{2}$ values should cause higher HONO values and Fig. $4 \mathrm{c}$ should reflect this trend. The lack of this trend was attributed to the fact that in contrast to studies in urban areas low $\mathrm{NO}_{2}$ mixing ratios were prevailing. About $90 \%$ of the $\mathrm{NO}_{2}$ values were below $5 \mathrm{ppb}$ and $70 \%$ of the values ranged between 1 and $4 \mathrm{ppb}$, indicating quite constant $\mathrm{NO}_{2}$ levels. The highest $\mathrm{HONO}$ and $\mathrm{HONO} / \mathrm{NO}_{\mathrm{x}}$ values typically occurred before or around midnight (see Fig. 2) at moderate $(2-5 \mathrm{ppb}) \mathrm{NO}_{2}$ mixing ratios, whereas the highest $\mathrm{NO}_{\mathrm{x}}$ values occurred in the morning hours (advection from road traffic). The weak correlation of $\mathrm{HONO}$ to $\mathrm{NO}_{\mathrm{x}}$ does not necessarily mean that $\mathrm{NO}_{2}$ is not a precursor for HONO. We simply do not see a correlation, which is similar to results from another rural forest site (Zhou et al., 2002a). This indicates that other processes like deposition or re-emission are also important.
Nevertheless, conversion frequencies, as summarized above, are within the range of values reported in literature. Referring to the different conditions and methods used in these experiments, this range is narrow and might provide some guidance for modelling studies.

\subsection{HONO mixing ratio differences and coupling regimes}

The investigation of the coupling regimes of the forest to the air layer above the canopy, as well as the coupling inside the forest is crucial to study the surface-atmosphere exchange of trace gases. The shaded and more humid subcanopy featured different environmental conditions than the atmosphere above the canopy, where the humidity was lower and photochemistry was more active. Vertical mixing processes link these two environments. As an indicator for the effectiveness of vertical mixing, the detection of coherent structures was used. Thomas and Foken (2007) state that the strong vertical motion typically associated with coherent structures enables them to penetrate deeply into the canopy forcing an exchange of air between different regions of the canopy. The residence time of air is therefore assumed to be controlled by the arrival frequency of coherent structures and limits the time available for physical, chemical and photochemical transformation of constituents within the canopy. Coherent structures are well organized in contrast to the randomlike distributed turbulence (Holmes et al., 1996). They cause typical ramp like structures in time series of e.g. $\mathrm{CO}_{2}$ and $\mathrm{H}_{2} \mathrm{O}$ and can thus be separated from random-like turbulence, e.g. with a wavelet tool (Thomas and Foken, 2005). A more 


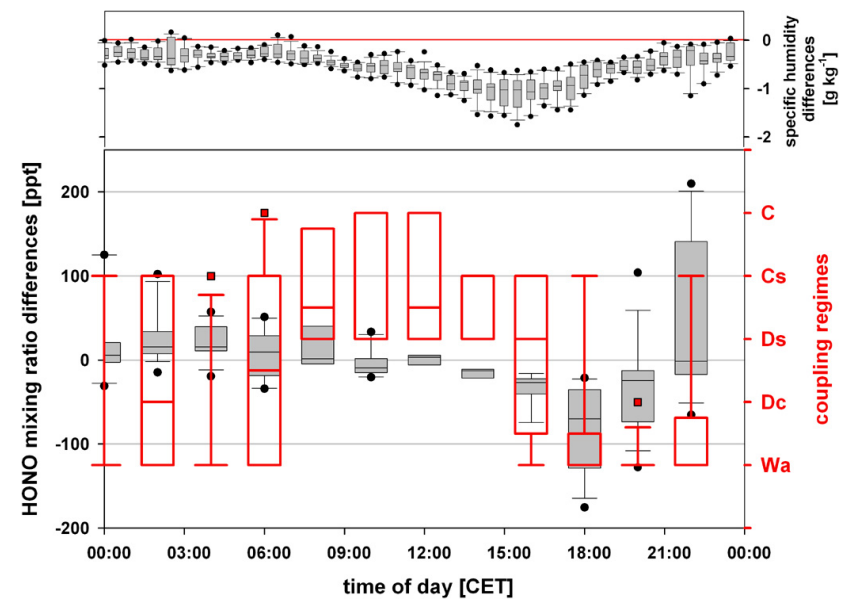

Fig. 5. Box-and-whisker plot for coupling regimes (red open bars) and HONO mixing ratio differences (grey filled bars) for the five-day dry period 20-25 September 2007 at the "WaldsteinWeidenbrunnen" research site. Wa (Wave motion $\sim$ no turbulent exchange), Dc (decoupled canopy $\sim$ whole canopy decoupled from the air layer above), Ds (decoupled subcanopy $\sim$ only subcanopy decoupled), Cs (coupled by sweeps $\sim$ canopy and subcanopy coupled by sweep motion) and C (fully coupled canopy). The upper panel shows the specific humidity difference between $21 \mathrm{~m}$ and the forest floor for comparison. The upper end of the boxes represents the $75^{t h}$ percentile, the lower end the 25 th percentile and the line within the boxes the median. Whiskers denote the 10th (lower whisker) and 90th (upper whisker) percentiles. Outliers are marked as points (HONO difference) or squares (coupling regimes). If only whiskers appear, there are no other values between the values marked by the whiskers. For the boxes at 10:00 and 14:00 the median falls in line with the lower end of the boxes (Ds).

detailed analysis of sensible heat exchange provides information about the portion of the canopy controlled by coherent exchange (exchange regimes). Thomas and Foken (2007) defined five different coupling regimes:

Wave motion (Wa). The flow above the canopy is dominated by linear wave motion rather than by turbulence, and therefore decoupled from the subcanopy and the canopy.

Decoupled canopy $(D c)$. The air above the canopy is decoupled from the canopy, because there is no transfer of energy and matter into and out of the canopy by coherent structures.

Decoupled subcanopy $(D s)$. The layer above the canopy is coupled to the canopy, but decoupled from the subcanopy.

Coupled sub canopy by sweeps (Cs). The coherent exchange between the canopy air and the subcanopy is forced by strong sweep motion of coherent structures only.

Fully coupled canopy $(C)$. The layer above the canopy, the canopy and the sub canopy are in a fully coupled state.

The detailed analysis of the coherent exchange and the coupling regimes for this particular experiment is given in Serafimovich et al. (2010).

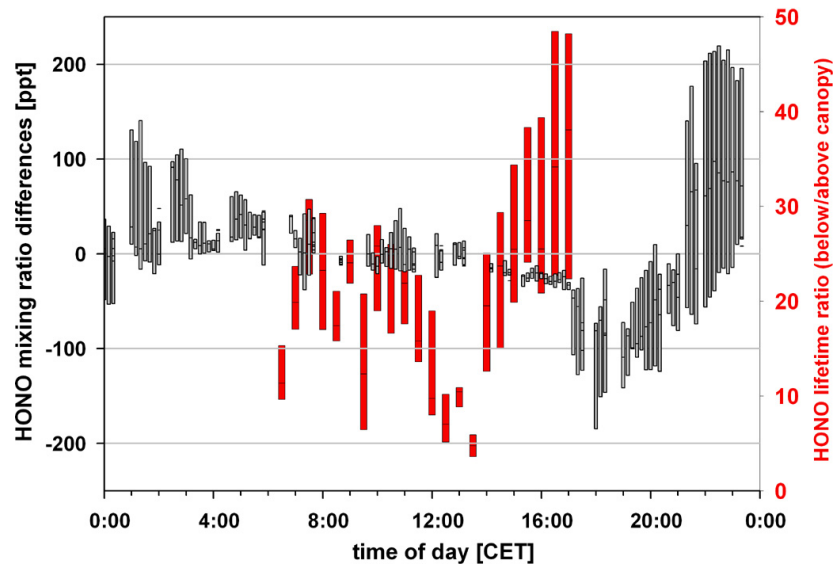

Fig. 6. HONO mixing ratio differences (grey bars, $10 \mathrm{~min}$ averages) and lifetime ratios (below to above canopy) (red bars, $30 \mathrm{~min}$ averages) for the five-day dry period 20-25 September 2007 at the "Waldstein-Weidenbrunnen" research site. The upper end of the boxes represents the 75th percentile, the lower end the 25 th percentile and the line within the boxes the median.

The diel cycle of HONO mixing ratio differences (above canopy minus below canopy) shown in Figs. 5 and 6 can be subdivided into four typical periods:

1. Early night (17:30-21:00 CET): There was no photolytic sink (sunset at 17:30 CET), but also no turbulent exchange (Wa). These were from a micrometeorological perspective the most stable conditions during the day, with a complete decoupling of the forest from the layer above the canopy (Wa, Dc). Due to the increasing nighttime values in the dry period, absolute HONO differences increased as well and induced a higher variability at nighttime (Fig. 5). Mixing ratio differences of up to minus $170 \mathrm{ppt}$ were measured. The higher HONO mixing ratios close to the forest floor in the early night can be explained by formation of HONO at the ground surface and accumulation in the trunk space, since the exchange with the layer above the canopy was very limited due to the decoupling of the forest. Above the canopy, mixing ratios increased at a lower rate or were fairly constant during this period, resulting in negative mixing ratio differences. The increasing differences could be observed similarly in the specific humidity (Fig. 5), which was not affected by photolysis or chemical reactions. The sign of the HONO mixing ratio differences changed during the early night at about 21:00 CET, when mixing ratios above canopy rose quickly and exceeded the values measured near the ground. This effect was more pronounced at the end of the dry period, when nighttime maximum values were much higher than during the first two days after the rain event. 


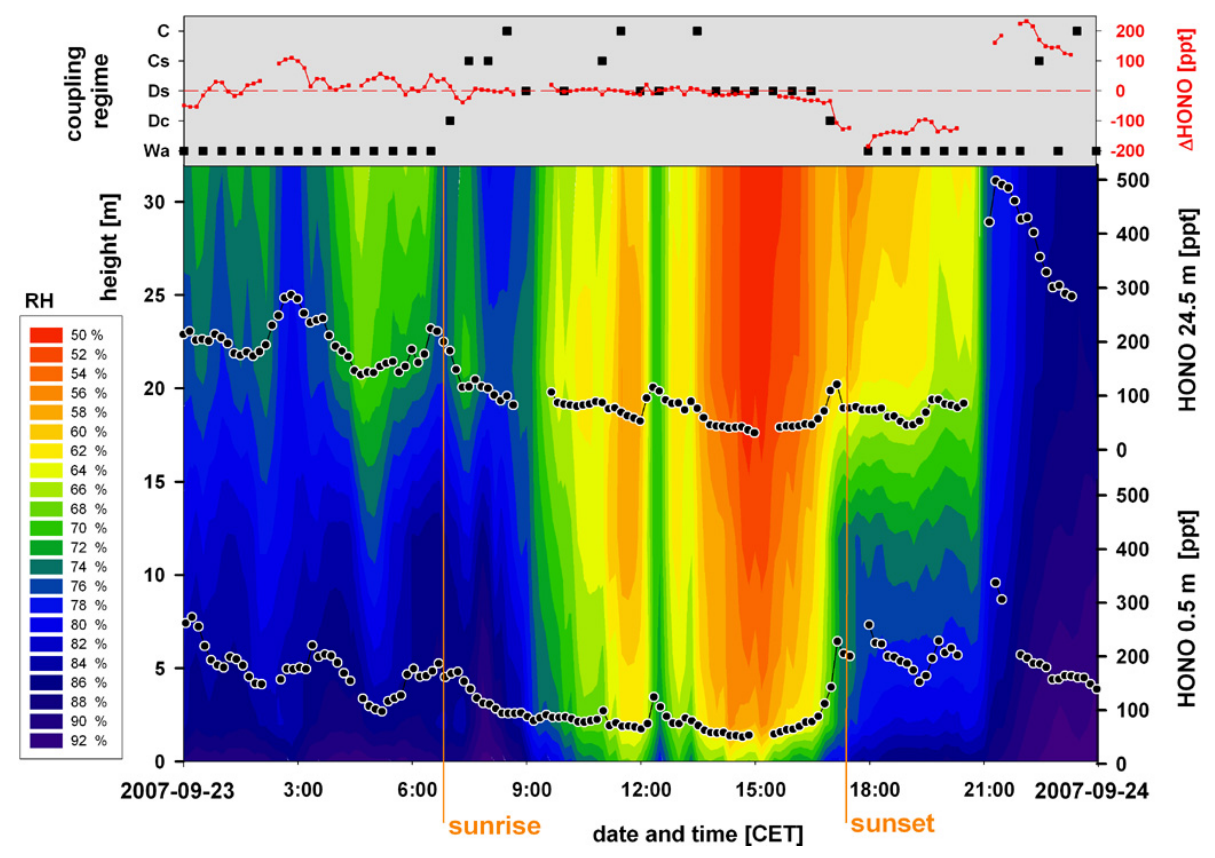

Fig. 7. Simultaneous HONO time series at $0.5 \mathrm{~m}$ (lower graph, circles and lines) and $24.5 \mathrm{~m}$ (upper graph, circles and lines), overlaid with a contour plot of the vertical profile of measured RH (colour-coded 50-92\%) for 23 September 2007 at the "Waldstein-Weidenbrunnen" research site. Missing values in the $\mathrm{HONO}$ measurements are due to zero air measurements. Sunrise and sunset (inferred from $j\left(\mathrm{NO}_{2}\right)$ as a proxy for $j(\mathrm{HONO})$ and global radiation measurements) are marked as vertical (orange) lines. The upper panel shows the mixing ratio differences between $24.5 \mathrm{~m}$ and $0.5 \mathrm{~m}(\Delta \mathrm{HONO})$ and the coupling regimes in the forest.

2. Late night to early morning (21:00-06:30 CET): Increasing mixing ratios above the canopy, exceeding the values below the canopy caused positive mixing ratio differences (max. $\sim 240 \mathrm{ppt}$ ). The main contribution to the large positive differences originates from the last two days (of the dry period) when mixing ratios where highest. On the 23rd this increase can be attributed to an air mass change (see Sect. 3.4). On the 24th wind direction changes but other than on the 23 rd other trace gases exhibit no significant change. In addition to these two extreme values, $\mathrm{HONO}$ and $\mathrm{HONO} / \mathrm{NO}_{\mathrm{x}}$ are predominantly higher above the canopy all the time from 21:00 to sunrise. We see a relation to RH but can only speculate about the reasons, which might be e.g., a mechanism similar to that proposed by Trick (2004). On the other hand, at nighttime the HONO lifetime is only limited by deposition and thus quite long. Thus, advection may also be a possible explanation. To distinguish between advection and local emission more measurements and an adequate modelling approach would be required.

3. Early morning to noon (06:30-13:00 CET): HONO mixing ratios decreased at both heights due to photolysis. The mixing ratio differences were close to zero (within the uncertainty of both instruments, see Sect. 3.1), although photolytic lifetimes differed by a factor of 10-25 (median values) between both heights
(Fig. 6). Around noon of clear-sky days, lifetimes were about $10 \mathrm{~min}$ above and 100-250 min below the canopy. If no exchange between both heights had occurred, a steep mixing ratio gradient should be observed. However, coupling of all forest compartments to the layer above the canopy was achieved during this period, as indicated by the dominance of $\mathrm{C}$ and $\mathrm{Cs}$ coupling regimes with Ds intermissions (Fig. 5). Hence, effective mixing has offset the differences in HONO lifetimes due to photolysis (Fig. 6).

4. Afternoon (13:00-17:30 CET): When decoupling of the subcanopy (Ds) became the predominant regime in the early afternoon (13:00 CET) and HONO lifetime ratios increased to a factor of 25-40 (median values), we always measured negative mixing ratio differences with a surprisingly low variation over the entire dry period (Figs. 5 and 6).

The HONO/NO $\mathrm{N}_{\mathrm{x}}$ vertical differences (not shown) have a similar diel cycle (see Figs. 5 and 6), as variations were mainly caused by the HONO mixing ratios (see Sect. 3.2). Differences were in the range of $-6 \%$ (evening) to $+5 \%$ (at night) and around zero from early morning to noon (very similar to HONO itself). Therefore, changes in the HONO mixing ratio differences can be attributed to changes in source or sink processes leading to higher (or lower) values in relation to $\mathrm{NO}_{\mathrm{x}}$ values. Under conditions with virtually 
no turbulent exchange of the forest with the layer above canopy (Dc and Wa regimes), which occurred in the late afternoon/early night, we found systematically higher values below canopy. This is an indication that HONO was formed and/or released at the ground.

The diel cycle of the mixing ratio differences can be explained by differences in source and sink processes throughout the canopy, whereas the magnitude of these mixing ratio differences is determined by the exchange conditions as derived from the coherent structures.

\subsection{Case study: 23 September}

In order to exemplify the interplay of different HONO source and sink processes, Fig. 7 shows a contour plot of RH and the HONO mixing ratios measured at 0.5 and $24.5 \mathrm{~m}$ above the ground on 23 September.

From midnight to 06:30 CET, HONO mixing ratios were typically higher above the canopy than below. The $\mathrm{HONO} / \mathrm{NO}_{\mathrm{x}}$ ratios were between 6 and $10 \%$ at both heights. We found a positive correlation $\left(r^{2}=0.78\right)$ with $\mathrm{RH}$ at $24.5 \mathrm{~m}$ but no correlation at the lower height $\left(r^{2}=0.07\right)$ during the same time period. This might be attributed to higher RHs up to $90 \%$ at the ground, representing a transition to a completely wetted vegetation surface (i.e. formation of epicuticular water films) above 90\% RH (Burkhardt and Eiden, 1994; Klemm et al., 1998; Lammel, 1999) thus leading to HONO uptake.

During the first two hours after sunrise (06:3008:30 CET), HONO mixing ratios decreased continuously with a rate of $60 \mathrm{ppth}^{-1}$ above the canopy and with $40 \mathrm{ppth}^{-1}$ close to the forest floor. If only photolysis was active, the calculated loss rate (i.e., $j(\mathrm{HONO}) \times[\mathrm{HONO}]$ ) above the canopy would be faster $\left(76 \mathrm{ppth}^{-1}\right)$ than observed. Below the canopy, the calculated loss rate would be much slower $\left(5.5 \mathrm{ppt} \mathrm{h}^{-1}\right)$ due to shading. This discrepancy can be explained by vertical mixing. Downward mixing of HONOdepleted air from aloft resulted in a much faster loss rate below the canopy than calculated from photolysis alone. The overall HONO loss is expected to be faster than the photolytic loss alone since the mixed layer growth in the morning contributes to a decrease of near surface HONO that was trapped in the thermodynamically stable NBL.

From 08:30CET until noontime, slightly decreasing HONO mixing ratios (10-15 $\mathrm{ppth}^{-1}$ most likely due to photolysis and mixing) were accompanied by a fast decrease of RH by $6 \% \mathrm{~h}^{-1}$ due to surface heating, causing rising surface temperatures. Therefore both measured variables were well correlated, but the correlation was mainly driven by radiation. Even though HONO lifetimes above and below canopy differ by a factor of 10 to 25 (median values) in the morning (Fig. 6), the difference in HONO mixing ratios is less than 5 ppt (Fig. 7 upper panel) from 10:00 to 12:00 CET, which is within the uncertainty of both instruments. This can be ex- plained by vertical exchange, taking place within the HONO lifetime above canopy.

Just after noontime, we observed a pronounced increase of $\mathrm{HONO}$ mixing ratios and of $\mathrm{HONO} / \mathrm{NO}_{\mathrm{x}}$ ratios at both heights, with a simultaneous increase of RH by $10 \%$. These patterns were most likely caused by passing clouds, increasing the HONO lifetime by a factor of three (from $9 \mathrm{~min}$ to 26 min above canopy, see Fig. 3), but were also related to a change in wind direction.

After the noontime peak, HONO mixing ratios decreased again at both heights but with a lower rate below canopy due to the 10 times lower photolysis frequencies. Further increases of lifetime ratios in the afternoon from 25 to 40 may have contributed to the increasing differences. While these differences were counter-balanced by effective vertical mixing, as indicated by a predominantly full coupling of the forest to the air layer above the canopy $(\mathrm{C}, \mathrm{Cs})$ in the morning hours, in the afternoon the HONO mixing ratio differences were maintained due to a lack of effective vertical mixing in the decoupled subcanopy (Ds) regime. Thus, only during periods when the subcanopy or even the whole forest are decoupled from the layer above the canopy, the different loss and production processes acting close to the forest floor and in the upper canopy become obvious. We propose a combination of lifetime differences due to shading of the canopy and the intensity of vertical mixing to explain the observed mixing ratio differences during daytime.

About two hours before sunset, HONO mixing ratios started to increase at both measurement heights. Above canopy, an increase rate of $40 \mathrm{ppth}^{-1}$ led to a slightly higher level of HONO mixing ratios of $70 \pm 16 \mathrm{ppt}$, whereas close to the forest floor, an increase rate of about $90 \mathrm{ppth}^{-1}$ resulted in a higher and nearly constant level of about $200 \pm 20$ ppt. The steep increase in HONO mixing ratios at the ground coincided with an obvious RH increase below canopy, which is not as pronounced as above canopy.

After sunset, photolysis no longer affects the atmospheric lifetime of HONO. Thus, the occurrence of different HONO mixing ratios and at the same time different $\mathrm{HONO} / \mathrm{NO}_{\mathrm{x}}$ ratios (about 5\% higher below canopy) at the two measuring heights provide evidence for different HONO-source processes throughout the canopy. The slight increase above the canopy and the strong increase below canopy in the absence of solar radiation and turbulent exchange with the air layer above canopy (Wa) give a strong indication that HONO was formed and released at the ground. We found a good correlation $\left(r^{2}=0.74\right)$ of HONO and RH for the whole period from 16:00 to 20:30 CET close to the forest floor due to accumulation of HONO and humidity below the canopy after decoupling of the forest. Above the canopy the correlation coefficient is very weak $\left(r^{2}=0.3\right)$.

Between 20:30 and 21:00 CET a steep increase of HONO mixing ratios was observed. This event is considered to be dominated by an air mass change and not by local HONO production or release, although there are no clear signals in 
wind speed or direction. But almost all quantities (except NO) changed substantially (see Fig. 3). For example, ozone mixing ratios dropped by about $20 \mathrm{ppb}$ (at $24.5 \mathrm{~m}$ ), $\mathrm{RH}$ increased by $16 \%$ from 20:30 to 22:00 CET and $\mathrm{NO}_{\mathrm{x}}$ increased from about $2 \mathrm{ppb}$ to $4.5 \mathrm{ppb}$, which could not be explained by local chemistry alone. Maximum HONO mixing ratios were reached at 21:30 CET with $480 \mathrm{ppt}$ above and $340 \mathrm{ppt}$ below the canopy. This resulted in $\mathrm{HONO} / \mathrm{NO}_{\mathrm{x}}$ ratios of up to $18 \%$ above the canopy.

After 21:00 CET, the HONO mixing ratios decreased again at both heights while RH continued to increase. Thus, a negative RH dependence was observed with coefficients of determination of 0.9 at $24.5 \mathrm{~m}$ height $(\mathrm{RH}=78-85 \%)$ and 0.94 at $0.5 \mathrm{~m}$ height $(\mathrm{RH}=88-93 \%)$. The slopes are nearly identical but the humidity range is very different. Therefore, it is speculative at best to draw any conclusions about the underlying physical or chemical processes. Although we often found a good correlation of HONO and $\mathrm{RH}$, we could not infer a simple relationship between RH and HONO mixing ratios. One reason for this is that both quantities exhibited a diel cycle that was affected by different (independent) environmental factors, e.g. radiation. HONO was formed near the ground and accumulated during nighttime, whereas $\mathrm{RH}$ increased due to cooling of the surface and evaporation still occurring in the afternoon and subsequent accumulation. During daytime HONO was photolyzed, whereas RH decreased due to surface heating although evaporation is enhanced. HONO and RH both decreased during daytime due to dilution by mixing with dryer and HONO depleted air from aloft. The only obvious relation are declining $\mathrm{HONO}$ mixing ratios at RHs above $95 \%$ as already observed by $\mathrm{Yu}$ et al. (2009).

\section{Conclusions}

For the first time, we have measured HONO mixing ratios simultaneously at two heights within and above a forest canopy using interference-corrected wet chemical analyzers (two LOPAP instruments). The instruments agreed within $12 \%(2 \sigma)$ during side-by-side measurements under fair and relatively dry weather periods, allowing for a detailed interpretation of the measured mixing ratio differences. The measured HONO mixing ratios were influenced by a combination of several processes, such as (a) available surface area for heterogeneous formation, (b) co-deposition of species related to HONO formation, (c) HONO desorption from the surface and interaction with RH and (d) turbulent exchange of air masses between the forest and the atmosphere above (coupling).

The combination of micrometeorological and chemical measurements allowed us to explain the diel variations of the HONO mixing ratio differences measured below and above a spruce forest canopy. Differences of source or sink processes between above and below canopy became obvious only dur- ing periods when they were not overcome by turbulent mixing. For example, rising mixing ratios close to the forest floor in the late afternoon and early night, when the forest canopy was decoupled from the air layer above, provided a clear indication of HONO formation at the ground surface. Higher mixing ratios above the forest canopy in the late night until the morning were in some cases due to advection above the forest, which did only partly penetrate the canopy. In the morning, vertical exchange was most efficient and thus differences in HONO mixing ratios varied around zero despite large differences of photolysis frequencies (factor of 10-25) below and above the canopy.

Moreover, we observed a build-up of HONO during dry periods that was not related to a build-up of its precursor $\mathrm{NO}_{2}$. We could not infer a simple relationship between $\mathrm{RH}$ and HONO mixing ratios. This study particularly demonstrated the strong effect of turbulent vertical transport and the influence of humidity conditions on HONO mixing ratios within and above the forest canopy. Nevertheless, in order to further untangle and quantify all different HONO sources and sinks, additional measurements both in the laboratory and in the field are required.

Acknowledgements. The authors gratefully acknowledge financial support by the German Science Foundation (DFG projects EGER, FO 226/16-1, ME 2100/4-1 and ZE 792/4-1) and by the Max Planck Society.

We are grateful to Ralph Dlugi, Eva Falge, Thomas Foken and Franz X. Meixner for intensive and fruitful discussions and to Jörg Kleffmann also for technical support during the measurements. We would like to thank Stefanie Schier for providing the SODAR data.

Edited by: J. G. Murphy

\section{References}

Alicke, B., Platt, U., and Stutz, J.: Impact of nitrous acid photolysis on the total hydroxyl radical budget during the Limitation of Oxidant Production Pianura/Padana Produzione di Ozono study in Milan, J. Geophys. Res., 107, 8196, doi:10.1029/2000JD000075, 2002.

Ammann, M., Kalberer, M., Arens, F., Lavanchy, V., Gäggler, H. W., and Baltensperger, U.: Nitrous acid formation on soot particles: Surface chemistry and the effect of humidity, J. Aerosol. Sci., 29, 1031-1032, 1998.

Ammann, M., Rössler, E., Strekowski, R., and George, C.: Nitrogen dioxide multiphase chemistry: Uptake kinetics on aqueous solutions containing phenolic compounds, Phys. Chem. Chem. Phys., 7, 2513-2518, doi:10.5194/acp-7-2513-2005, 2005.

Andrés-Hernández, M. D., Notholt, J., Hjorth, J., and Schrems, O.: A DOAS study on the origin of nitrous acid at urban and nonurban sites, Atmos. Environ., 30, 175-180, 1996.

Arens, F., Gutzwiller, L., Baltensperger, U., Gäggler, H. W., and Ammann, M.: Heterogeneous reaction of $\mathrm{NO}_{2}$ on diesel soot particles, Environ. Sci. Technol., 35, 2191-2199, 2001. 
Arens, F., Gutzwiller, L., Gäggeler, H. W., and Ammann, M.: The reaction of $\mathrm{NO}_{2}$ with solid anthrarobin (1,2,10-trihydroxyanthracene), Phys. Chem. Chem. Phys., 4, 3684-3690, 2002.

Aubin, D. G., and Abbatt, J. P. D.: Interaction of $\mathrm{NO}_{2}$ with hydrocarbon soot: focus on HONO yield, surface modification, and mechanism, J. Phys. Chem. A, 111, 6263-6273, 2007.

Ayers, G. P.: Comment on regression analysis of air quality data, Atmos. Environ., 35, 2423-2425, 2001.

Baldocchi, D., Falge, E., Gu, L., Olson, R., Hollinger, D., Running, S., Anthoni, P., Bernhofer, C., Davis, K., Evans, R., Fuentes, J., Goldstein, A., Katul, G., Law, B., Lee, X., Malhi, Y., Meyers, T., Munger, W., Oechel, W., Paw U, K. T., Pilegaard, K., Schmid, H. P., Valentini, R., Verma, S., Vesala, T., Wilson, K., and Wofsy, S.: FLUXNET: A new tool to study the temporal and spatial variability of ecosystem-scale carbon dioxide, water vapor, and energy flux densities, B. Am. Meteorol. Soc., 82, 2415-2434, 2001

Bejan, I., Aal, Y. A. E., Barnes, I., Benter, T., Bohn, B., Wiesen, P., and Kleffmann, J.: The photolysis of ortho-nitrophenols: a new gas phase source of HONO, Phys. Chem. Chem. Phys., 8, 2028-2035, doi:10.1039/b516590c, 2006.

Bröske, R., Kleffmann, J., and Wiesen, P.: Heterogeneous conversion of $\mathrm{NO}_{2}$ on secondary organic aerosol surfaces: A possible source of nitrous acid (HONO) in the atmosphere?, Atmos. Chem. Phys., 3, 469-474, doi:10.5194/acp-3-469-2003, 2003.

Burkhardt, J. and Eiden, R.: Thin water films on coniferous needles, Atmos. Environ., 28, 2001-2017, 1994.

Calvert, J. G., Yarwood, G., and Dunker, A. M.: An evaluation of the mechanism of nitrous acid formation in the urban atmosphere, Res. Chem. Intermediat., 20, 463-502, 1994.

Febo, A., Perrino, C., and Allegrini, I.: Measurement of nitrous acid in Milan, Italy, by DOAS and diffusion denuders, Atmos. Environ., 30 3599-3609, 1996.

Finlayson-Pitts, B. J., Wingen, L. M., Sumner, A. L., Syomin, D., and Ramazan, K. A.: The heterogeneous hydrolysis of $\mathrm{NO}_{2}$ in laboratory systems and in outdoor and indoor atmospheres: An integrated mechanism, Phys. Chem. Chem. Phys., 5, 223-242, 2003.

Finlayson-Pitts, B. J.: Reactions at surfaces in the atmosphere: integration of experiments and theory as necessary (but not necessarily sufficient) for predicting the physical chemistry of aerosols, Phys. Chem. Chem. Phys., 11, 7760-7779, 2009.

Foken, T.: Micrometeorology, Springer, Berlin-Heidelberg, Germany, 308 pp., 2008.

Foken, T., Meixner, F. X. ,Falge, E. Zetzsch, C., Serafimovich, A., Bargsten, A., Behrendt, T., Biermann, T., Breuninger, C., Gerken, T., Hunner, M., Lehmann-Pape, L., Hens, K., Jocher, G., Kesselmeier, J., Lüers, J., Mayer, J.-C., Moravek, A., Plake, D., Riederer, M., Rütz, F., Scheibe, M., Schier, S., Siebicke, L., Sörgel, M., Staudt, K., Trebs, I., Tsokankunku, A., Welling, M., Wolf, V. and Zhu, Z.: Atmospheric transport and chemistry in forest ecosystems-overview of the EGER-project, in preparation, Bound.-Lay. Meteorol., 2011.

Frankenberger, E.: Untersuchungen über den Vertikalaustausch in den unteren Dekametern der Atmosphäre, Annalen der Meteorologie, 4, 358-374, 1951.

George, C., Strekowski, R. S., Kleffmann, J., Stemmler, K., and Ammann, M.: Photoenhanced uptake of gaseous $\mathrm{NO}_{2}$ on solid organic compounds: a photochemical source of HONO?, Fara- day Discuss., 130, 195-210, 2005.

Gerstberger, P., Foken, T., and Kalbitz, K.: The Lehstenbach and Steinkreuz catchments in NE Bavaria, in: Biogeochemistry of forested catchments in a changing environment: a German case study, edited by: Matzner, E., Ecological Studies, Springer Verlag, Heidelberg, Germany, 15-44, 2004.

Gower, S. T., Kucharik, C. J., and Norman, J. M.: Direct and indirect estimation of leaf area index, $\mathrm{f}_{A P A R}$, and net primary production of terrestrial ecosystems, Remote. Sens. Environ., 70, 29-51, 1999.

Gustafsson, R. J., Orlov, A., Griffiths, P. T., Cox, R. A., and Lambert, R. M.: Reduction of NO2 to nitrous acid on illuminated titanium dioxide aerosol surfaces: implications for photocatalysis and atmospheric chemistry, Chem. Commun., 37, 3936-3938, 2006.

Gustafsson, R. J., Kyriakou, G., and Lambert, R. M.: The molecular mechanism of tropospheric nitrous acid production on mineral dust surfaces, Chem. Phys. Chem., 9, 1390-1393, 2008.

Gutzwiller, L., Arens, F., Baltensberger, U., Gäggler, H. W., and Ammann, M.: Significance of semivolatile diesel exhaust organics for secondary HONO formation, Environ. Sci. Technol., 36, 677-682, 2002a.

Gutzwiller, L., George, C., Rössler, E., and Ammann, M.: Reaction kinetics of $\mathrm{NO}_{2}$ with resorcinol and 2,7-naphthalenediol in the aqueous phase at different pH, J. Phys. Chem. A, 106, 1204512050, 2002b.

Hanst, P. L., Spence, J. W., and Miller, M.: Atmospheric chemistry of n-nitroso dimethylamine, Environ. Sci. Technol., 11 403-405, 1977.

Harrison, R. M. and Kitto, A.-M. N.: Evidence for a surface source of atmospheric nitrous acid, Atmos. Environ., 28, 1089-1094, 1994.

He, Y., Zhou, X., Hou, J., Gao, H., and Bertman, S. B.: Importance of dew in controlling the air-surface exchange of HONO in rural forested environments, Geophys. Res. Lett., 33, L02813, doi:10.1029/2005GL024348, 2006.

Heland, J., Kleffmann, J., Kurtenbach, R., and Wiesen, P.: A new instrument to measure gaseous nitrous acid (HONO) in the atmosphere, Environ. Sci. Technol., 35, 3207-3212, 2001.

Holmes, P., Lumley, J. L., and Berkooz, G.: Turbulence, coherent structures, dynamical systems and symmetry, Cambridge University Press, Cambridge, 420 pp., 1996.

Jenkin, M. E., Cox, R. A., and Williams, D. J.: Laboratory studies of the kinetics of formation of nitrous acid from the thermal reaction of nitrogen dioxide and water vapour, Atmos. Environ., 22, 487498, 1988.

Killus, J. P. and Whitten, G. Z.: Background reactivity in smog chambers, Int. J. Chem. Kinet., 22, 547-575, 1990.

Kleffmann, J., Becker, K. H., and Wiesen, P.: Heterogeneous $\mathrm{NO}_{2}$ conversion processes on acid surfaces: possible atmospheric implications, Atmos. Environ., 32, 2721-2729, 1998.

Kleffmann, J., Becker, K. H., Lackhoff, M., and Wiesen, P.: Heterogeneous conversion of $\mathrm{NO}_{2}$ on carbonaceous surfaces, Phys. Chem. Chem. Phys., 1, 5443-5450, 1999.

Kleffmann, J., Heland, J., Kurtenbach, R., Lörzer, J., and Wiesen, P.: A new instrument (LOPAP) for the detection of nitrous acid (HONO), Environ. Sci. Pollut. R., 4, 48-54, 2002.

Kleffmann, J., Kurtenbach, R., Lörzer, J., Wiesen, P., Kalthoff, N., Vogel, B., and Vogel, H.: Measured and simulated vertical 
profiles of nitrous acid - Part I: Field measurements, Atmos. Environ., 37, 2949-2955, 2003.

Kleffmann, J., Benter, T., and Wiesen, P.: Heterogeneous reaction of nitric acid with nitric oxide on glass surfaces under simulated atmospheric conditions, J. Phys. Chem. A, 108, 5793-5799, 2004.

Kleffmann, J., Gavriloaiei, T., Hofzumahaus, A., Holland, F., Koppmann, R., Rupp, L., Schlosser, E., Siese, M., and Wahner, A.: Daytime formation of nitrous acid: A major source of $\mathrm{OH}$ radicals in a forest, Geophys. Res. Lett., 32, L05818, doi:10.1029/2005GL022524, 2005.

Kleffmann, J.: Manual LOPAP-3, version 1.3.0, Bergische Universität Wuppertal, QUMA Elektronik \& Analytik GmbH, Wuppertal, Germany, 2006.

Kleffmann, J., Lörzer, J. C., Wiesen, P., Kern, C., Trick, S., Volkamer, R., Rodenas, M., and Wirtz, K.: Intercomparison of the DOAS and LOPAP techniques for the detection of nitrous acid (HONO), Atmos. Environ., 40, 3640-3652, 2006.

Kleffmann, J.: Daytime sources of nitrous acid (HONO) in the atmospheric boundary layer, Chem. Phys. Chem., 8, 1137-1144, 2007.

Klemm, O., Burkhardt, J., and Gerchau, J.: Leaf wetness: A quantifiable parameter in deposition studies, in: Proceedings of the EUROTRAC-2 Symposium 98: Transport and chemical transformation in the troposphere, edited by: Borell, P. M. and Borell, P., WIT press, Southampton, UK, 238-242, 1999.

Kraus, A. and Hofzumahaus, A.: Field measurements of atmospheric photolysis frequencies for $\mathrm{O}_{3}, \mathrm{NO}_{2}, \mathrm{HCHO}, \mathrm{CH}_{3} \mathrm{CHO}$, $\mathrm{H}_{2} \mathrm{O}_{2}$, and $\mathrm{HONO}$ by UV spectroradiometry, J. Atmos. Chem., 31, 161-180, 1998.

Lammel, G. and Perner, D.: The atmospheric aerosol as a source of nitrous acid in the polluted atmosphere, J. Aerosol. Sci., 19, 1199-1202, 1988.

Lammel, G. and Cape, J. N.: Nitrous acid and nitrite in the atmosphere, Chem. Soc. Rev., 25, 361-369, 1996.

Lammel, G.: Formation of nitrous acid: Parameterisation and comparison with observations, Max Planck Institute for Meteorology, Hamburg, Germany, report No. 286, 36, 1999.

Legendre, P. and Legendre, L.: Numerical ecology, 2nd English ed., Developments in environmental modelling, Elsevier Science BV, Amsterdam, The Netherlands, 1998.

Monge, M. E., D’Anna, B., Mazri, L., Giroir-Fendler, A., Ammann, M., Donaldson, D. J., and George, C.: Light changes the atmospheric reactivity of soot, P. Natl. Acad. Sci. USA, 107, 66056609,2010

Moravek, A.: Vertical distribution of reactive and non-reactive trace gases in and above a spruce canopy, master thesis, University Karlsruhe, Germany, 124 pp., 2008.

Ndour, M., D’Anna, B., George, C., Ka, O., Balkanski, Y., Kleffmann, J., Stemmler, K., and Ammann, M.: Photoenhanced uptake of $\mathrm{NO}_{2}$ on mineral dust: Laboratory experiments and model simulations, Geophys. Res. Lett., 35, L05812, doi:10.1029/2007GL032006, 2008.

Notholt, J., Hjorth, J., and Raes, F.: Formation of $\mathrm{HNO}_{2}$ on aerosol surfaces during foggy periods in the presence of $\mathrm{NO}$ and $\mathrm{NO}_{2}$, Atmos. Environ., 26, 211-217, 1992.

Oren, R., Schulze, E.-D., Matyssek, R., and Zimmermann, R.: Estimating photosynthetic rate and annual carbon gain in conifers from specific leaf weight and leaf biomass, Oecologia, 70, 187-
193, 1986.

Perner, D. and Platt, U.: Detection of nitrous acid in the atmosphere by differential optical absorption, Geophys. Res. Lett., 6, 917920, 1979.

Pitts Jr., J. N., Biermann, H. W., Winer, A. M., and Tuazon, E. C.: Spectroscopic identification and measurement of gaseous nitrous acid in dilute auto exhaust, Atmos. Environ., 18, 847-854, 1984.

Pitts Jr., J. N., Grosjean, D., Cauwenberghe, K. V., Schmid, J. P., and Fitz, D. R.: Photooxidation of aliphatic amines under simulated atmospheric conditions: formation of nitrosamines, nitramines, amides, and photochemical oxidant, Environ. Sci. Technol., 12 946-953, 1978.

Qin, M., Xie, P., Su, H., Gu, J., Peng, F., Li, S., Zeng, L., Liu, J., Liu, W., and Zhang, Y.: An observational study of the HONO$\mathrm{NO}_{2}$ coupling at an urban site in Guangzhou City, South China, Atmos. Environ., 43, 5731-5742, 2009.

Reisinger, A. R.: Observations of $\mathrm{HNO}_{2}$ in the polluted winter atmosphere: possible heterogeneous production on aerosols, Atmos. Environ., 34, 3865-3874, 2000.

Rohrer, F., Bohn, B., Brauers, T., Bruning, D., Johnen, F.-J., Wahner, A., and Kleffmann, J.: Characterisation of the photolytic HONO-source in the atmosphere simulation chamber SAPHIR, Atmos. Chem. Phys., 5, 2189-2201, doi:10.5194/acp-5-21892005, 2005.

Rubio, M. A., Lissi, E., and Villena, G.: Nitrite in rain and dew in Santiago city, Chile. Its possible impact on the early morning start of the photochemical smog, Atmos. Environ., 36, 293-297, 2002.

Rubio, M. A., Lissi, E., and Villena, G.: Factors determining the concentration of nitrite in dew from Santiago, Chile, Atmos. Environ., 42, 7651-7656, 2008.

Sakamaki, F., Hatakeyama, S., and Akimoto, H.: Formation of nitrous acid and nitric oxide in the heterogeneous dark reaction of nitrogen dioxide and water vapour, Int. J. Chem. Kinet., 15, 1013-1029, 1983.

Saliba, N. A., Yang, H., and Finlayson-Pitts, B. J.: Reaction of gaseous nitric oxide with nitric acid on silica surfaces in the presence of water at room temperature, J. Phys. Chem. A, 105, 10339-10346, 2001.

Sander, R.: Compilation of Henry's law constants for inorganic and organic species of potential importance in environmental chemistry, available at: http://www.mpch-mainz.mpg.de/ $\sim$ sander/res/ henry.html, last access: 4 January 2011, 1999.

Serafimovich, A., Siebicke, L., Staudt, K., Lüers, J., Biermann, T., Schier, S., Mayer, J.-C., Foken, T.: ExchanGE processes in mountainous Regions (EGER) Documentation of the Intensive Observation Period (IOP1) September, 6th to October, 7th 2007, Arbeitsergebnisse Nr. 36, Bayreuth, Germany, print ISSN 16148916; internet ISSN 1614-8924, 2008

Serafimovich, A., Thomas, C., and Foken, T.: Vertical and horizontal transport of energy and matter by coherent motions in a tall spruce canopy, Bound.-Lay. Meteorol., in review, 2011.

Sjödin, A: Studies of the diurnal variation of nitrous acid in urban air, Environ. Sci. Technol., 22, 1086-1089, 1988.

Sleiman, M., Gundel, L. A., Pankow, J. F., Jacob, P., Singer, B. C., and Destaillats, H.: Formation of carcinogens indoors by surfacemediated reactions of nicotine with nitrous acid, leading to potential thirdhand smoke hazards, P. Natl. Acad. Sci. USA, 107, 6576-6581, 2010 
Sokal, R. R. and Rohlf, F. J.: Biometry - The principles and practice of statistics in biological research, 3rd ed., W. H. Freeman, New York, USA, 1995.

Sonntag, D.: Important new values of the physical constants of 1986, vapor pressure formulations based on the ITS-90 and psychrometer formulae, Z. Meteorol., 70, 340-344, 1990.

Staudt, K. and Foken, T.: Documentation of reference data for the experimental areas of the Bayreuth Centre for Ecology and Environmental Research (BayCEER) at the Waldstein site, University of Bayreuth, Dept. of Micrometeorology Bayreuth, report No. 37, print ISSN 1614-8916; internet ISSN 1614-8924, 2007.

Staudt, K., Falge, E., Pyles, R. D., Paw U, K. T., and Foken, T.: Sensitivity and predictive uncertainty of the ACASA model at a spruce forest site, Biogeosciences, 7, 3685-3705, doi:10.5194/bg-7-3685-2010, 2010.

Stemmler, K., Ammann, M., Donders, C., Kleffmann, J., and George, C.: Photosensitized reduction of nitrogen dioxide on humic acid as a source of nitrous acid, Nature, 440, 195-198, 2006.

Stemmler, K., Ammann, M., Elshorbany, Y., Kleffmann, J., Ndour, M., D’Anna, B., George, C., and Bohn, B.: Light induced conversion of nitrogen dioxide into nitrous acid on submicron humic acid aerosol, Atmos. Chem. Phys., 7, 4237-4248, doi:10.5194/acp-7-4237-2007, 2007.

Stull, R. B.: An Introduction to Boundary Layer Meteorology, Atmospheric and Oceanographic Sciences Library, Kluwer Academic Publishers, Dordrecht, The Netherlands, 670 pp., 1988.

Stutz, J., Alicke, B., and Neftel, A.: Nitrous acid formation in the urban atmosphere: Gradient measurements of $\mathrm{NO}_{2}$ and $\mathrm{HONO}$ over grass in Milan, Italy, J. Geophys. Res., 107(D22), 8192, doi:10.1029/2001JD000390, 2002.

Stutz, J., Alicke, B., Ackermann, R., Geyer, A., Wang, S., White, A. B., Williams, E. J., Spicer, C. W., and Fast, J. D.: Relative humidity dependence of HONO chemistry in urban areas, J. Geophys. Res., 109, D03307, doi:10.1029/2003JD004135, 2004.

Su, H., Cheng, Y. F., Cheng, P., Zhang, Y. H., Dong, S., Zeng, L. M., Wang, X., Slanina, J., Shao, M., and Wiedensohler, A.: Observation of nighttime nitrous acid (HONO) formation at a nonurban site during PRIDE-PRD2004 in China, Atmos. Environ., 42, 6219-6232, 2008.

Svensson, R., Ljungström, E., and Lindqvist, O.: Kinetics of the reaction between nitrogen dioxide and water vapour, Atmos. Environ., 21 1529-1539, 1987.

Thomas, C. and Foken, T.: Detection of long-term coherent exchange over spruce forest using wavelet analysis, Theor. Appl. Climatol., 80, 91-104, 2005.

Thomas, C. and Foken, T.: Flux contribution of coherent structures and its implications for the exchange of energy and matter in a tall spruce canopy Bound.-Lay. Meteorol., 123, 317-337, doi:10.1007/s10546-006-9144-7, 2007.
Trebs, I., Bohn, B., Ammann, C., Rummel, U., Blumthaler, M., Königstedt, R., Meixner, F. X., Fan, S., and Andreae, M. O.: Relationship between the NO2 photolysis frequency and the solar global irradiance, Atmos. Meas. Tech., 2, 725-739, doi:10.5194/amt-2-725-2009, 2009.

Trick, S.: Formation of nitrous acid on urban surfaces - a physicalchemical perspective, Ph.D. thesis, University Heidelberg, Heidelberg, Germany, 290 pp., 2004.

Veitel, $\mathrm{H} .:$ Vertical profiles of $\mathrm{NO}_{2}$ and HONO in the boundary layer, Ph.D. thesis, University Heidelberg, Heidelberg, Germany, 270 pp., 2002.

Vogel, B., Vogel, H., Kleffmann, J., and Kurtenbach, R.: Measured and simulated vertical profiles of nitrous acid - Part II. Model simulations and indications for a photolytic source, Atmos. Environ., 37, 2957-2966, 2003.

Wainmann, T., Weschler, C. J., Lioy, P. J., and Zhang, J.: Effects of surface type and relative humidity on the production and concentration of nitrous acid in a model indoor environment, Environ. Sci. Technol., 35, 2200-2206, 2001.

Wolff, V., Trebs, I., Foken, T., and Meixner, F. X.: Exchange of reactive nitrogen compounds: concentrations and fluxes of total ammonium and total nitrate above a spruce canopy, Biogeosciences, 7, 1729-1744, doi:10.5194/bg-7-1729-2010, 2010.

Yu, Y., Galle, B., Hodson, E., Panday, A., Prinn, R., and Wang, S.: Observations of high rates of $\mathrm{NO}_{2}-\mathrm{HONO}$ conversion in the nocturnal atmospheric boundary layer in Kathmandu, Nepal, Atmos. Chem. Phys., 9, 6401-6415, doi:10.5194/acp-9-6401-2009, 2009.

Zhang, N., Zhou, X., Shepson, P. B., Gao, H., Alaghmand, M., and Stirm, B.: Aircraft measurement of HONO vertical profiles over a forested region, Geophys. Res. Lett., 36, L15820, doi:10.1029/2009GL038999, 2009.

Zhou, X., Civerolo, K., Dai, H., Huang, G., Schwab, J., and Demerjian, K.: Summertime nitrous acid chemistry in the atmospheric boundary layer at a rural site in New York State, J. Geophys. Res., 107(D21), 4590, doi:10.1029/2001JD001539, 2002a.

Zhou, X., He, Y., Huang, G., Thornberry, T. D., Carroll, M. A., and Bertman, S. B.: Photochemical production of nitrous acid on glass sample manifold surface, Geophys. Res. Lett., 29(14), 1681, doi:10.1029/2002GL015080, 2002b.

Zhou, X., Gao, H., He, Y., Huang, G., Bertman, S. B., Civerolo, K., and Schwab, J.: Nitric acid photolysis on surfaces in low- $\mathrm{NO}_{\mathrm{x}}$ environments: Significant atmospheric implications, Geophys. Res. Lett., 30(23), 2217, doi:10.1029/2003GL018620, 2003. 